\title{
Pemodelan Proses Bisnis PMB Menggunakan Pendekatan Berorientasi Objek berbasis Prototyping dengan Metodologi RAD
}

\author{
Yasmiati $^{1}$, Suwarni ${ }^{2}$, Desmiwati $^{3}$, Andi Susilo $^{4}$ \\ 1,2,3Program Studi Ilmu Komputer, Fakultas Teknologi Informasi, \\ Universitas Respati Indonesia \\ ${ }^{4}$ Program Studi Teknologi Informasi, Fakultas Teknik \\ Universitas Darma Persada \\ Email: 1'yasmiati@fti.urindo.ac.id, 22suwarni@fti.urindo.ac.id, \\ 3desmiwati@fti.urindo.ac.id, ${ }^{4}$ andi_susilo@ft.unsada.ac.id
}

\begin{abstract}
Abstrak
Kegiatan Penerimaan Mahasiswa Baru (PMB) merupakan tahapan awal seorang calon mahasiswa masuk ke perguruan tinggi. Aplikasi Sistem penerimaan mahasiswa baru menjadi bagian yang penting dalam mendukung layanan yang maksimal kepada calon mahasiswa. Studi ini menganalisis proses bisnis dengan pemodelan fungsional. Metode Rapid Application Development (RAD) berbasis Prototyping kami gunakan dalam pengembangan sistem dengan pendekatan berorientasi objek. Disain riset secara spesifik menguraikan empat tahap yaitu identifikasi, pemodelan, dokumentasi, dan terakhir verifikasi dan validasi proses bisnis dan model fungsionalnya. Riset ini menunjukkan bahwa proses bisnis dan model fungsional dapat secara optimal selaras dengan kebutuhan fungsional sistem.
\end{abstract}

Kata kunci: PMB, proses bisnis, pemodelan fungsional, RAD, dan Prototyping

Abstract

The New Student Admissions (PMB) activity is the initial stage of a prospective student entering college. Application The new student admission system is an important part in supporting maximum service to prospective students. This study analyses business processes with functional modelling. We use Prototyping-based Rapid Application Development (RAD) method in developing systems with an object-oriented approach. The research design specifically describes four stages, namely identification, modelling, documentation, and finally the verification and validation of business processes and their functional models. This research shows that business processes and functional models can be optimally aligned with the functional requirements of the system.

Keywords: PMB, business process, functional modelling, RAD, and Prototyping

\section{Pendahuluan}

Menurut Permendikbud No. 6 Tahun 2020 bahwa Penerimaan Mahasiswa baru harus dilakukan dengan terbuka dan hasilnya dapat diakses oleh semua pihak dengan mudah, dilaksanakan dengan prosedur dan persyaratan yang jelas, dilakukan dengan adil tidak membedakan agama, ras, jenis kelamin, kemampuan ekonomi, dan kedudukan sosial calon mahasiswa [1]. 
Kebijakan yang ditempuh dalam proses rekrutmen mahasiswa baru selalu dimulai dari proses koordinasi antara pimpinan Universitas, Direktorat Pasca/Fakultas dengan Ketua Program Studi dalam hal penentuan daya tampung, dan kriteria atau persyaratan pendaftaran.
Tujuan PMB di URINDO adalah menghasilkan masukan proses pendidikan dengan kualifikasi sesuai program studi yang dituju dan memenuhi ambang batas ukuran yang menjamin kesuksesan dalam menempuh studi sampai lulus, serta memberikan peluang untuk mendapatkan calon mahasiswa yang terbaik.

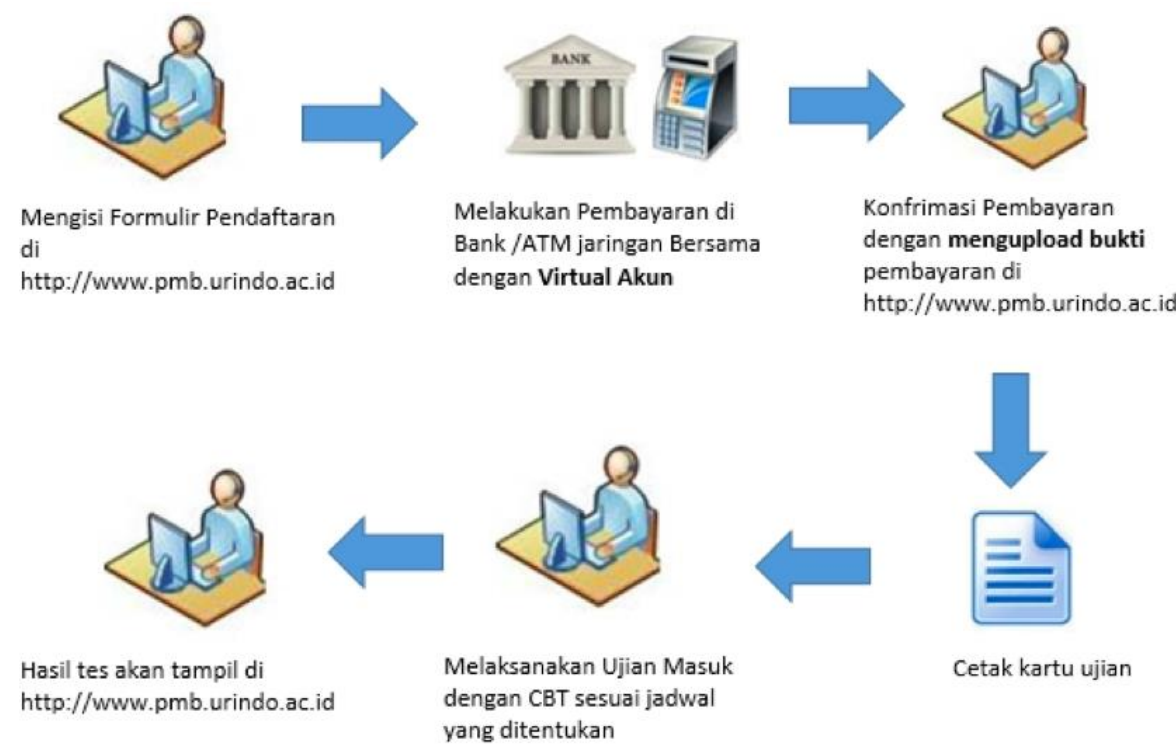

Gambar 1 Alur penerimaan mahasiswa baru

Sejak tahun 2017 penerimaan mahasiswa baru (PMB) telah dilaksanakan secara daring. Alur proses pendaftaran mahasiswa terlihat pada gambar 1.

Berdasarkan data pada aplikasi OSS (One Stop Service), Universitas Respati Indonesia (URINDO) memiliki student body berjumlah 2432 mahasiswa aktif dan sebanyak 593 mahasiswa baru pada Tahun Akademik 2020-2021.

Dalam penelitian ini kami akan melakukan analisis proses bisnis dan pemodelan fungsional dengan pendekatan berorientasi objek pada penerimaan mahasiswa baru (PMB) di
Universitas Respati Indonesia (URINDO).

\section{Metode}

Metode pengembangan sistem secara standar mengacu kepada System Development Life Cycle (SDLC) melalui empat fase yaitu Perencanaan (planning), Analisis (Analysis), Perancangan (Design), dan Implementasi (Implementation). Model Waterfall tidak cocok untuk proyek yang kompleks dan tidak direkomendasikan untuk pengembangan perangkat lunak berorientasi objek, untuk proyek jangka 
panjang atau yang sedang berlangsung, atau untuk proyek yang tidak diketahui atau persyaratan variabel [2].

Tabel 1 Kriteria pemilihan metodologi

\begin{tabular}{llll}
\hline \multirow{2}{*}{ Kriteria } & \multicolumn{3}{l}{ Metodologi RAD } \\
\cline { 2 - 4 } & Phased & Prototyping & $\begin{array}{l}\text { Throwaway } \\
\text { Prototyping }\end{array}$ \\
\hline Kebutuhan pengguna tidak jelas & Baik & Unggul & Unggul \\
Teknologi yang tidak dikenal & Baik & Kurang & Unggul \\
Sistem yang kompleks & Baik & Kurang & Unggul \\
Sistem yang handal & Baik & Kurang & Unggul \\
Jadwal yang pendek & Unggul & Unggul & Baik \\
Jadwal yang dapat dimonitor & Unggul & Unggul & Baik \\
\hline
\end{tabular}

Tabel 1 memperlihatkan kriteria yang kami bandingkan dengan memilih metodologi yang spesifik yaitu metodologi Rapid Application Development (RAD). Model RAD adalah sebuah pengembangan yang cepat dan berulang di mana umpan balik pemilik produk merupakan elemen yang diperlukan, sebelum merilis versi final [3].

Gambar 2 memperlihatkan metodologi RAD berbasis Prototyping sebagai metodologi yang kami pilih, karena kami nilai paling tepat dalam merepresentasikan pengembangan sistem penerimaan mahasiswa baru.

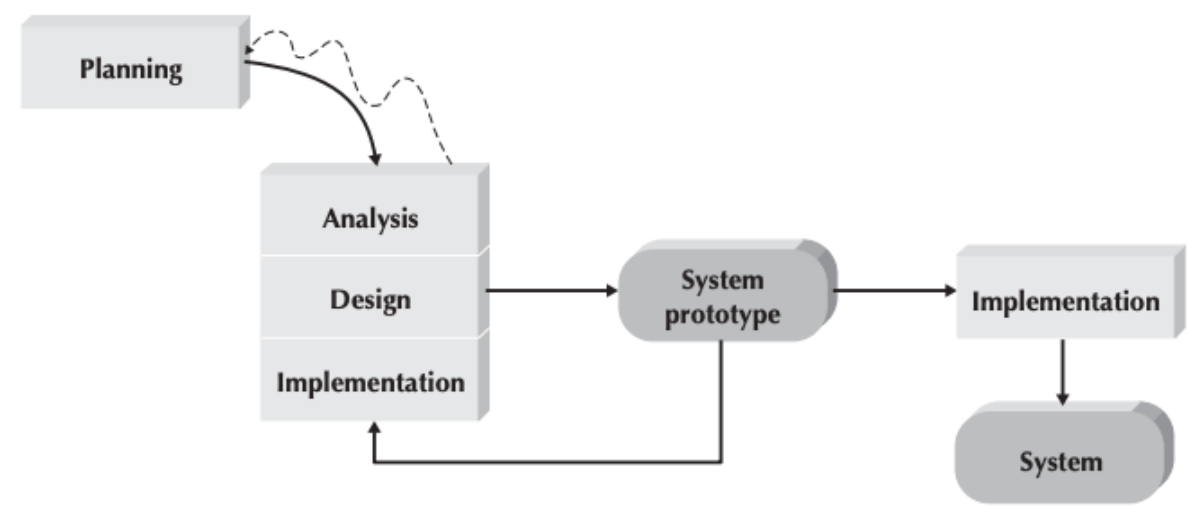

Gambar 2 Metodologi berbasis Prototyping 


\section{Metode}

Dalam penelitian ini kami fokus kepada fase analisis dari proses bisnis dan pemodelan fungsional yang diperkenalkan oleh Dennis, Wixom, dan Tegarden [4] menggunakan pendekatan berorientasi objek dengan disain riset seperti terlihat pada gambar 3 .

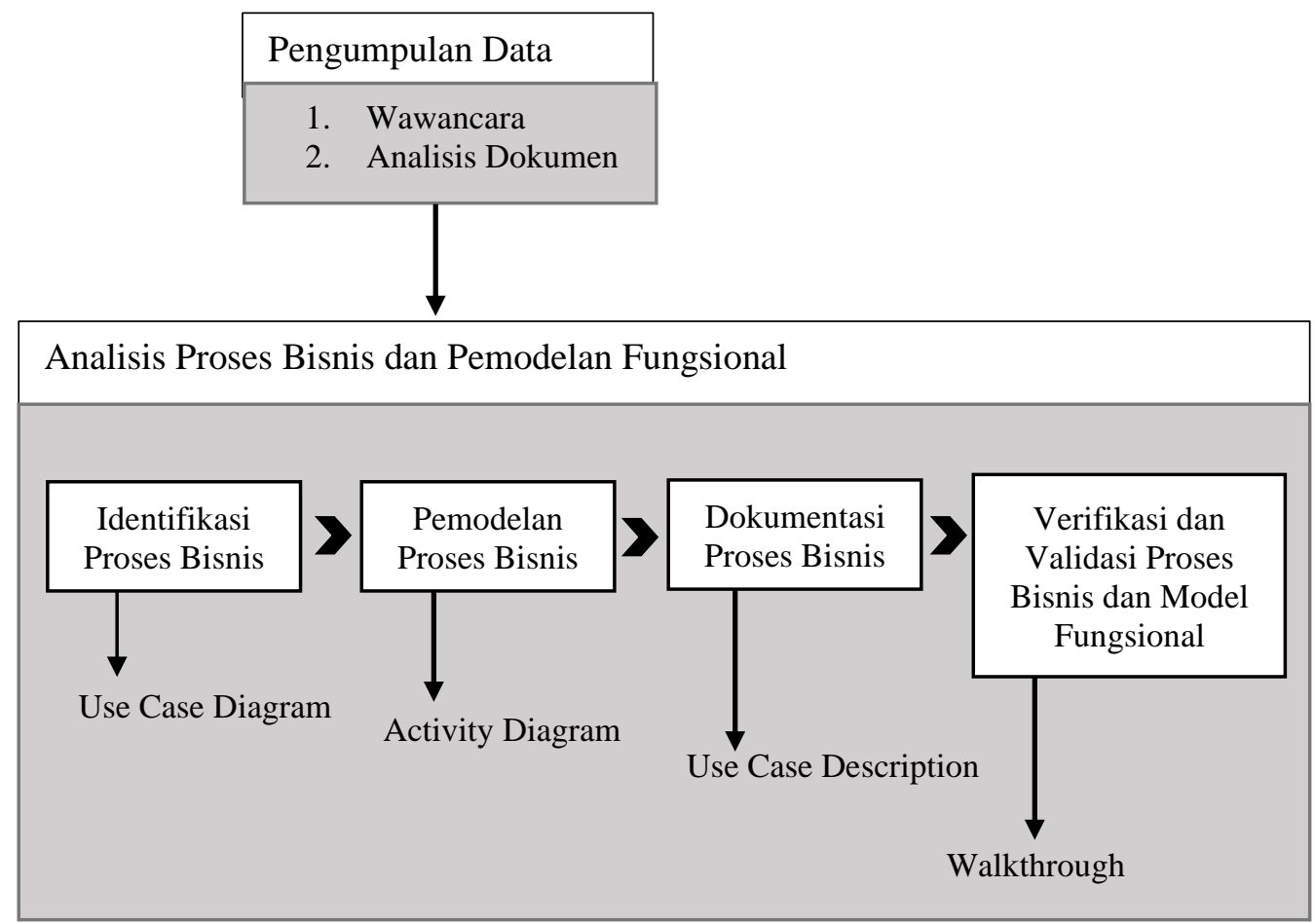

Gambar 3 Disain riset proses bisnis dan pemodelan fungsional

Tahap awal dari disain riset ini adalah pengumpulan kebutuhan (requirement gathering) berdasarkan penggambaran sistem awal (as is system) dari penerimaan mahasiswa baru. Kami menggunakan dua teknik pengumpulan data yaitu wawancara melalui openended question, dan closed-ended question. Kami melakukan wawancara tertulis dengan petugas PMB. Teknik kedua adalah analisis dokumen melalui dokumen prosedur penerimaan mahasiswa baru.

Setelah mengetahui alur sistem awal, kami melakukan analisis lebih dalam dari proses bisnis dan model fungsionalnya menggunakan empat tahap yaitu identifikasi proses bisnis, pemodelan proses bisnis, dokumentasi proses bisnis, dan verifikasi dan validasi proses bisnis dan model fungsional.

\section{Hasil}

Detail empat tahap dari pemodelan fungsional pada fase analisis sebagai berikut:

Tahap 1 Indentifikasi Proses Bisnis

Pada tahap ini kami akan memodelkan proses bisnis dengan uses cases dan use case diagram untuk memahami fungsionalitas sistem yang lebih baik. Kami secara dominan menggunakan tool aplikasi StarUML untuk membuat pemodelan fungsional ini.

Elemen use case diagram meliputi aktor, use case, batasan subjek, dan serangkaian relasi antar aktor, aktor dan 
use case, dan use case dengan use case. Relasi ini terdiri asosiasi, include, extend, dan relasi generalisasi antar aktor. Use case diagram menyediakan pandangan yang luas fungsionalitas dasar proses bisnis dari sistem yang berkembang. Gambar 4 memperlihatkan use case diagram penerimaan mahasiswa baru.

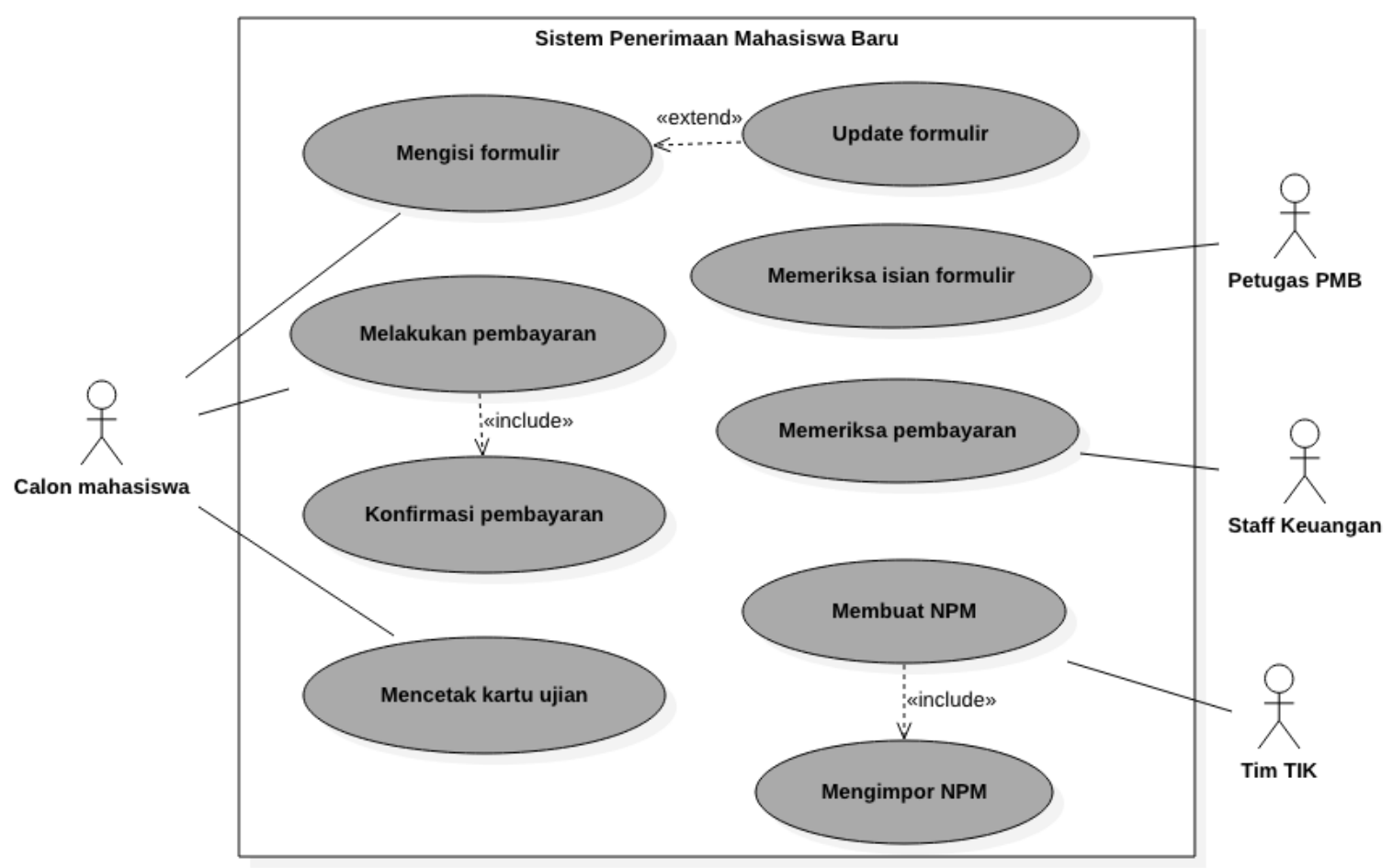

Gambar 4 Use Case Diagram Penerimaan Mahasiswa baru

\section{Tahap 2 Pemodelan Proses Bisnis}

Pada tahap kedua ini, kami menggunakan activity diagram untuk memodelkan tingkah laku di dalam sebuah proses bisnis dengan objek-objek yang terpisah. Activity diagram menyediakan tampilan grafis yang lebih detail dari kegiatan-kegiatan yang mendukung setiap proses bisnis. Cakupan activity diagram pada tahap ini dibatasi untuk mendokumentasikan dan memodelkan proses bisnis level atas. Gambar 5 memperlihatkan activity diagram penerimaan mahasiswa baru dengan objek-objek terpisah melalui swimlane. 


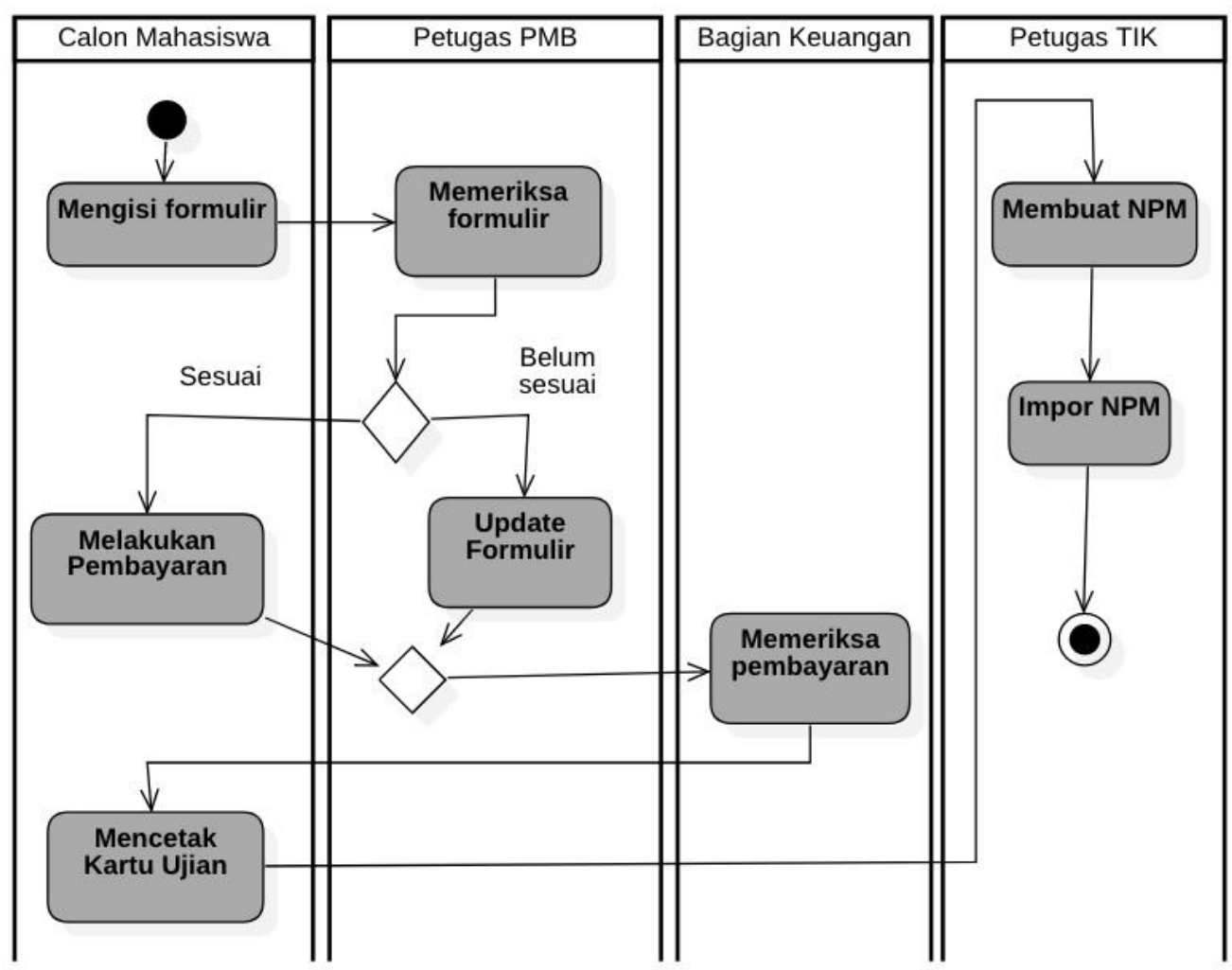

Gambar 5 Activity Diagram Penerimaan Mahasiswa baru dengan objek-objek terpisah

Pengembangan dari UML 2.0 Activity Diagram (UML 2.0-AD) memungkinkan persyaratan keamanan ditentukan dalam domain proses bisnis [5].

\section{Tahap 3 Dokumentasi Proses Bisnis}

Tahap ketiga ini, kami melakukan dokumentasi proses bisnis menggunakan use case description. Use case description berisi seluruh informasi yang diperlukan untuk mendokumentasikan fungsionalitas proses bisnis. Use case description didasarkan kepada identifikasi kebutuhan, use case diagram, dan deskripsi-deskripsi activity diagram proses bisnis pada tahap 1 dan
2. Use case adalah blok-blok bangunan yang mana sistem dirancang dan dibangun dan juga sebagai pengendali utama dari seluruh teknik diagram Unified Modeling Language (UML). Gambar 6 memperlihatkan use case description Mengisi Formulir. Keseluruhan use case pada use case diagram harus juga dibuat use case description masing-masing.

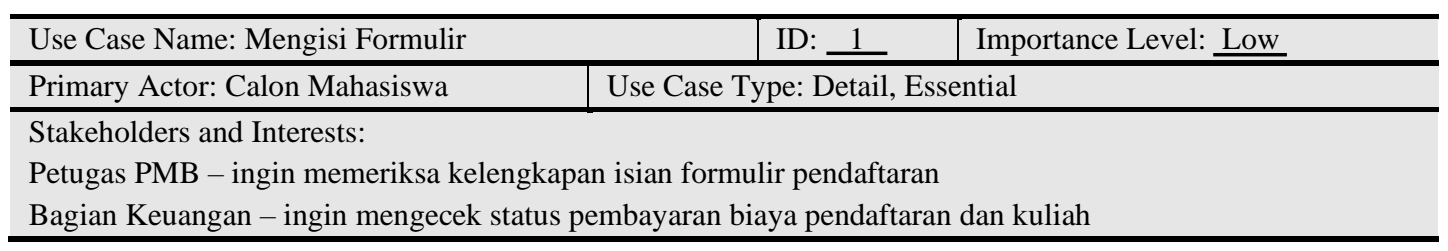




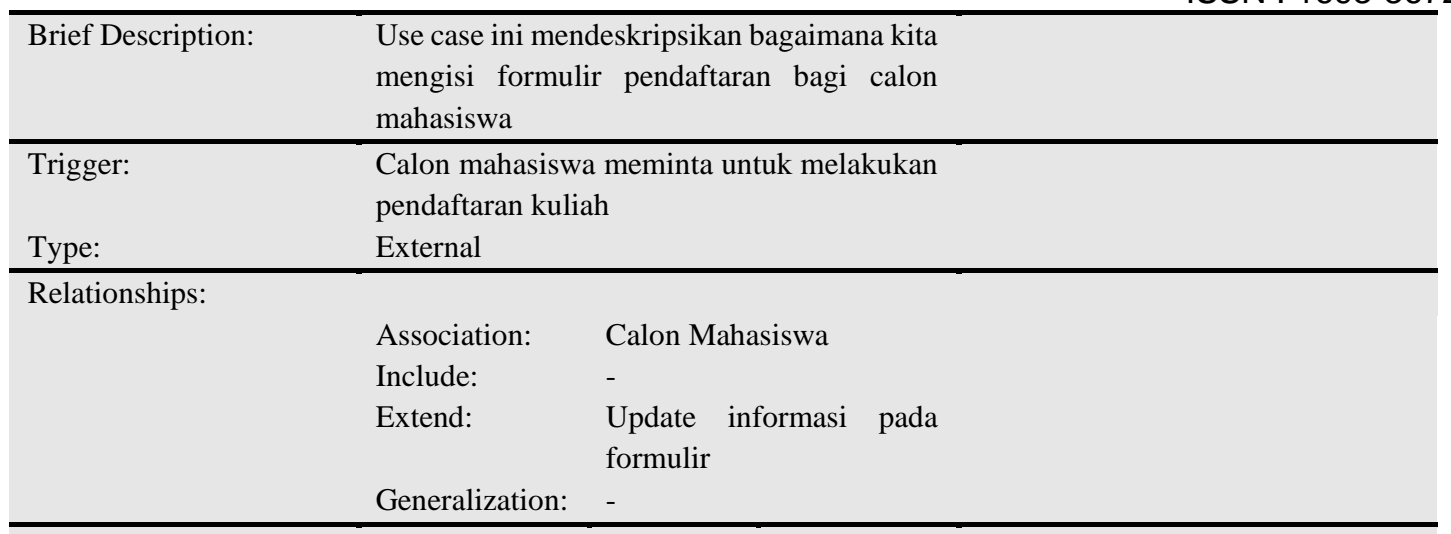

Normal Flow of Events:

1. Calon mahasiswa mengontak kantor bagian PMB untuk mendaftar kuliah.

2. Calon mahasiswa menyediakan kepada petugas PMB nama, alamat, asal sekolah, ijasah dan nilai.

3. Jika informasi calon mahasiswa belum terisi lengkap,

Eksekusi use case update formulir.

4. Petugas PMB menanyakan jika calon mahasiswa akan mengisi pendaftaran ulang, mengubah, atau membatalkan pendaftaran.

Jika calon mahasiswa ingin mengisi ulang formulir,

S-1: subflow mengisi formulir baru dilaksanakan.

Jika calon mahasiswa ingin mengubah formulir,

S-2: subflow mengubah isi formulir dilaksanakan.

Jika calon mahasiswa ingin membatalkan pendaftaran,

S-3: subflow membatalkan pendaftaran kuliah dilaksanakan.

5. Petugas PMB menyediakan formulir yang sudah lengkap dan valid kepada calon mahasiswa.

\section{Subflows:}

S-1: Mengisi formulir baru

1. Petugas PMB menanyakan calon mahasiswa kemungkinan cara pengisian formulir.

2. Petugas PMB mencocokan mekanisme pendaftaran menurut keinginan calon mahasiswa.

S-2: Membatalkan pendaftaran kuliah

1. Petugas PMB menanyakan kepada calon mahasiswa kesesuaian pilihan jurusan atau waktu kuliah.

2. Petugas PMB mencari berkas isian formulir dan menghapusnya.

S-3: Mengubah isian formulir

1. Petugas PMB melaksanakan S-2: subflow membatalkan pendaftaran kuliah.

2. Petugas PMB melaksanakan S-1: subflow mengisi formulir baru

Alternate/Exceptional Flows:

S-2, 1a1: Petugas PMB mengajukan beberapa alternatif jadwal kuliah dan jurusan berdasarkan kepada latar belakang pendidikan dan waktu kerja.

S-2, 1a2: Calon mahasiswa memilih alternatif yang ditawarkan atau memutuskan tidak melanjutkan pendaftaran kuliah.

Gambar 6 Use case description Mengisi Formulir

Karena keterbatasan jumlah Pada tahap ini, kita perlu halaman yang diijinkan, maka kami melakukan verifikasi dan validasi hanya menguraikan satu use case model-model fungsional yang description dari sembilan use case digambarkan pada tahap 1 sampai 3 description yang diperlukan. untuk menjamin model-model tersebut description yang diperlukan. mewakili proses bisnis yang sedang

Tahap 4 Verifikasi dan validasi proses bisnis dan model fungsional dianalisis. Pengujian ini mencakup ketaatan setiap model dari activity diagram, use-case description, dan usecase diagram yang seluruhnya 
mendeskripsikan kebutuhan fungsional yang sama.

Kami menggunakan pendekatan walkthrough yaitu sebuah pendekatan manual untuk memverifikasi dan memvalidasi model-model yang sedang dikembangkan. Di dalam kasus pemodelan fungsional, pendekatan walkthrough yang kami laksanakan adalah melakukan kajian dari modelmodel dan diagram-diagram yang berbeda selama pemodelan fungsional. Kajian ini diselesaikan oleh tim pengembang dan klien (terutama Petugas PMB). Dengan walkthrough kami mengidentifikasi adanya kesalahan-kesalahan spesifikasi dari sistem yang sedang dianalisis. Setidaknya terdapat empat peran dalam melakukan walkthrough seperti terlihat pada tabel 2 .

Tabel 2 Peran utama dalam kegiatan walkthrough

\begin{tabular}{|l|l|}
\hline Peran & Tugas \\
\hline Presenter & $\begin{array}{l}\text { Seseorang yang bertanggung jawab merepresentasikan secara } \\
\text { spesifik model yang sedang dikaji. }\end{array}$ \\
\hline Recorder & $\begin{array}{l}\text { Seseorang yang bertanggung jawab merekam seluruh kejadian } \\
\text { yang muncul selama kegiatan walkthrough. Seluruh error yang } \\
\text { muncul harus bisa didokumentasikan. }\end{array}$ \\
\hline Maintenance & $\begin{array}{l}\text { Seseorang yang bertanggung jawab memunculkan isu-isu } \\
\text { pemeliharaan representasi. }\end{array}$ \\
\hline Moderator & $\begin{array}{l}\text { Seseorang yang bertanggung jawab dalam mengundang, } \\
\text { menngatur, dan menjalankan walkthrough meeting. }\end{array}$ \\
\hline
\end{tabular}

Dari pertemuan walkthrough kami menemukan bahwa Tim PMB perlu memverifikasi formulir yang telah diisi oleh calon mahasiswa dan Tim PMB juga harus mampu menambah, mengubah, dan menghapus file dari calon mahasiswa. Aktivitas tersebut belum nampak pada use case diagram pada gambar 4.

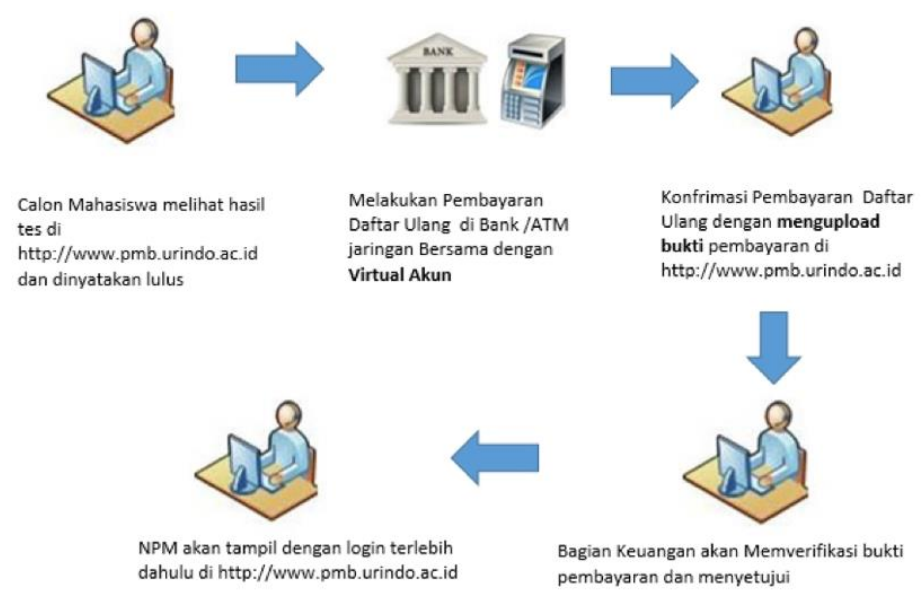

Gambar 7 Alur penerbitan NPM

Kami juga menemukan bahwa pada alur penerbitan NPM pada gambar 7 mensyaratkan calon mahasiswa untuk membayar biaya registrasi terlebih dahulu untuk mendapatkan NPM dan mengisi KRS. Berdasarkan dokumentasi tersebut kami memodifikasi use case diagram pada gambar 4 menjadi seperti terlihat pada gambar 8 . 


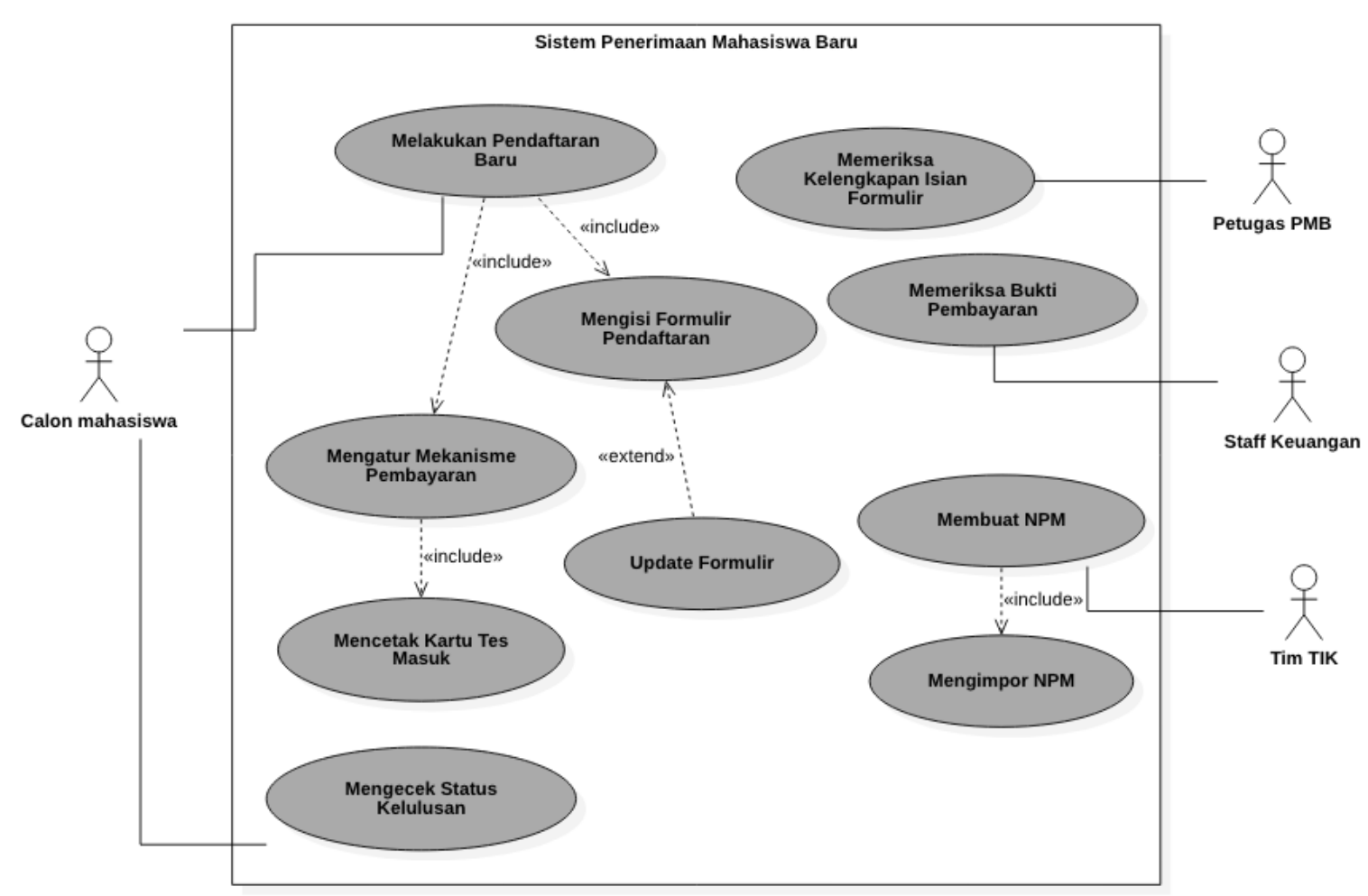

Gambar 8 Modifikasi Use Case Diagram Sistem Penerimaan Mahasiswa baru

\section{Simpulan}

Hasil studi dari tahap 1 sampai 4 dapat disimpulkan bahwa proses bisnis dengan pemodelan fungsional melalui use case, use case diagram, activity diagram, dan use case description dapat mendokumentasikan proses bisnis penerimaan mahasiswa baru secara utuh dan memenuhi tercapainya tujuan kepada kebutuhan fungsional yang optimal. Verifikasi dan validasi dengan pendekatan walkthrough terbukti dapat menemukan dengan cepat kesalahankesalahan (error) yang muncul dari setiap tahap dan model dan dalam tingkatan lanjut didokumentasikan dan dimodifikasi kembali sesuai dengan kebutuhan fungsional sistem dan permintaan klien.

\section{Daftar Pustaka}

[1] Kemendikbud, "Permendikbud No. 6 Tahun 2020 tentang Penerimaan Mahasiswa Baru," Permendikbud no. 6 Tahun 2020, no. 018903, pp. 1-12, 2020, [Online]. Available: https://jdih.kemdikbud.go.id/arsi p/Salinan PERMENDIKBUD 6 TAHUN 2020 FIX.pdf.

[2] P. Agarwal, A. Singhal, and A. Garg, "SDLC Model Selection Tool and Risk Incorporation," Int. J. Comput. Appl., vol. 172, no. 10, 2017, doi: 10.5120/ijca2017915143.

[3] F. Q. Khan, S. Rasheed, M. Alsheshtawi, T. M. Ahmed, and S. Jan, "A comparative analysis of RAD and agile technique for 
management of computing graduation projects," Comput. Mater. Contin., vol. 64, no. 2, 2020, doi:

10.32604/CMC.2020.010959.

[4] A. Dennis, B. Wixom, and D. Tegarden, System Analysis \& Design: An Object-Oriented Approach with UML, Fifth. John Wiley \& Sons, Inc., 2015.
[5] A. Rodríguez, E. FernándezMedina, J. Trujillo, and M. Piattini, "Secure business process model specification through a UML 2.0 activity diagram profile," Decis. Support Syst., vol. 51, no. 3, 2011, doi: 10.1016/j.dss.2011.01.018. 